\title{
Archaeomagnetic investigation of oriented pre-Columbian lime-plasters from Teotihuacan, Mesoamerica
}

\author{
A. M. Soler-Arechalde ${ }^{1}$, F. Sánchez ${ }^{1}$, M. Rodriguez ${ }^{1}$, C. Caballero-Miranda ${ }^{1}$, A. Goguitchaishvili ${ }^{1,2 *}$, \\ J. Urrutia-Fucugauchi ${ }^{1}$, L. Manzanilla ${ }^{3}$, and D. H. Tarling ${ }^{4}$ \\ ${ }^{1}$ Laboratorio de Paleomagnetismo, Instituto de Geofísica, Universidad Nacional Autonóma de México, \\ Delegación Coyoacán 04510 D.F., Mexico \\ ${ }^{2}$ Laboratorio Interinstitucional de Magnetismo Natural, Instituto de Geofísica, UNAM, Coeneo, Michoacán \\ ${ }^{3}$ Instituto de Investigaciones Antropológicas, Universidad Nacional Autónoma de México, Delegación Coyoacán 04510 D.F., Mexico \\ ${ }^{4}$ School of Earth Ocean and Environmental Sciences, University of Plymouth, Plymouth, U.K.
}

(Received December 19, 2005; Revised June 26, 2006; Accepted July 6, 2006; Online published November 8, 2006)

\begin{abstract}
Results of an archaeomagnetic study of two excavation field seasons at the Xalla and Teopancazco residential areas of the ancient Prehispanic city of Teotihuacan, Central Mexico are reported. One-hundred and fifty three oriented samples of lime-plasters from the two archaeological sites were collected for the study. NRM directions are reasonably well grouped. Alternating field demagnetization shows single or two-component magnetizations. Rock magnetic measurements point to fine-grained titanomagnetites with pseudo-single domain behaviour. Characteristic site mean directions from both sites are correlated to the available palaeosecular variation curve for Mesoamerica. The mean directions obtained from Xalla site point to average dates of $550 \mathrm{AD} \pm 25$ years that matches with the documented 'Big Fire' of Teotihuacan (AD 575). Two consecutive construction levels at Teopancazco were estimated as AD 250-350 and AD 350-425 respectively.
\end{abstract}

Key words: Archaeomagnetism, lime-plasters, geomagnetic secular variation, Teotihuacan, Mesoamerica.

\section{Introduction}

Many archaeological materials contain magnetic particles and acquire a remanence at some specific time that depends on the direction and intensity of Earth's magnetic field (e.g., Aitken, 1990; Lanos et al., 1999). The time of acquisition of remanent magnetization can be determined by comparison of the palaeomagnetic parameters of such materials from an archaeological site with an already dated record of the past geomagnetic field in the same region, known as a master or reference geomagnetic secular variation curve. Where the past variations of Earth's magnetic field, and thus the master curve, are well established, such as in Europe, archaeomagnetic dating can be as precise as radiometric dating (e.g., Genevey and Gallet, 2002) and does not depend on the availability of suitable carbonbearing material.

The use of lime-plasters (so called 'stuccos') was widespread in Mesoamerica. The Teotihuacan culture extensively employed plasters made of lime, lithic clasts and water, which were used for a variety of purposes in floors, sculptures, ceramics and supporting media for mural paintings, adding grinded volcanic scoria rich in iron that enhance the magnetic signal. Hueda-Tanabe et al. (2004) recently showed that both burned and unburned lime-plasters

\footnotetext{
*At sabbatical, Departamento de Geología y Mineralogía, Universidad Michoacana San Nicolás de Hidalgo, México.

Copyright (c) The Society of Geomagnetism and Earth, Planetary and Space Sciences (SGEPSS); The Seismological Society of Japan; The Volcanological Society of Japan; The Geodetic Society of Japan; The Japanese Society for Planetary Sciences; TERRAPUB.
}

may provide an accurate and reliable record of Earth's magnetic field at the time of their elaboration. This opens new possibilities to obtain high quality archaeomagnetic data considering that lime-plasters are abundant in archaeological sites in Mesoamerica.

In this study we report -new archaeomagnetic results of selected lime-plaster samples from Xalla and Teopancazco, two major archaeological residential areas of Teotihuacan. The study is aimed to investigate the magnetic record of lime-plasters and the potential use of the magnetization directions for archeomagnetic dating. A major limitation of the archaeomagnetic dating studies is related to the resolution and reliability of the geomagnetic secular variation curve for Mesoamerica. To improve the archaeomagnetic master curve for the region we require increased chronological resolution and further high-quality archaeomagnetic data.

\section{Sample Description}

Teotihuacan is one of the largest urban and religious centers in Mesoamerica, characterized by large temple pyramids, administrative sectors and many residential areas, covering an area of about $20 \mathrm{~km}^{2}$ (Fig. 1). A population of more than 100,000 people is estimated. The city was primarily occupied between AD 0 and AD 650. For the study, 136 lime-plaster samples were obtained from Xalla and 17 samples from Teopancazco, two sites excavated in the "Teotihuacan: elite and government" project, headed by Linda Manzanilla. Xalla samples were collected during 2001 and 2003 field trip, while Teopancazco was mainly sampled in 2003. The residential area of Teopancazco 


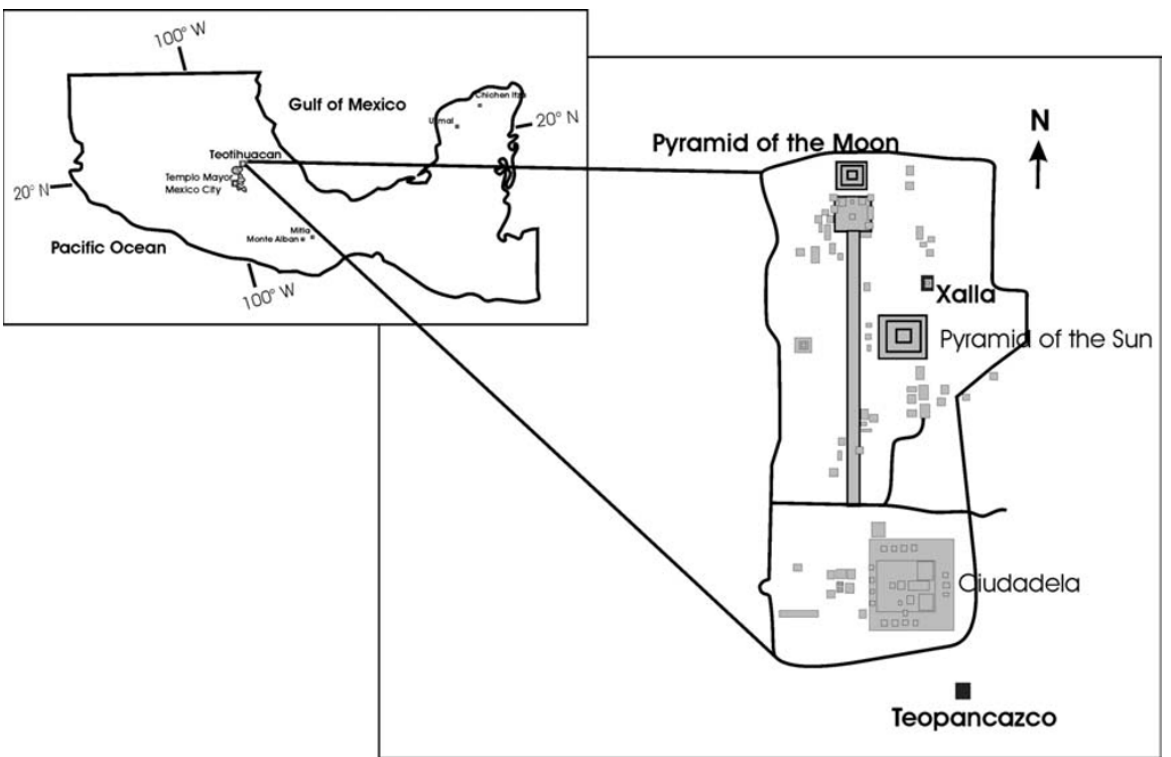

Fig. 1. Location of Teotihuacan and the sites of Teopancazco and Xalla (signal by a dark squares).

Table 1. Mean directions by sample and stage Xalla 2001. $N$ : number of specimens, DEC: declination, INC: inclination, $\alpha_{95}, R, K$ : Fisher statistical parameters, rejected if $\alpha_{95}>13^{\circ}, \mathrm{b}$-burned, non b-non burned, location parameters: $\mathrm{S}$-structure, $\mathrm{R}$-room, B-building, $\mathrm{N}$-north, E-east.

\begin{tabular}{|c|c|c|c|c|c|c|c|c|c|}
\hline Sample & $N$ & $\mathrm{DEC}$ & INC & $\alpha_{95}$ & $R$ & $K$ & & & Description \\
\hline Xa1 & $7 / 7$ & 340.6 & 41.1 & 9.47 & 6.716 & 21 & & & Floor 1 b S4R1 N349 E331 \\
\hline $\mathrm{Xa} 2$ & $8 / 10$ & 336.8 & 42.6 & 7.33 & 7.802 & 35 & & & Floor 1 b S4R1 N347 E339 \\
\hline $\mathrm{Xa3}$ & $7 / 7$ & 7.5 & 33.4 & 11.89 & 6.638 & 15 & & & Floor 1 b S4R1 N348 E339 \\
\hline $\mathrm{Xa} 4$ & $9 / 10$ & 359.3 & 38.8 & 5.91 & 8.834 & 48 & & & Floor 1 b S4R1 \\
\hline $\mathrm{Xa} 5$ & $9 / 10$ & 359.2 & 38.6 & 5.93 & 8.833 & 48 & & & Floor 1 non b S4R1 N335 E333 \\
\hline Xa6 & $9 / 10$ & 332.6 & 38.7 & 8.29 & 8.687 & 26 & & & Floor 1 non b S4R1 N346 E333 \\
\hline $\mathrm{Xa} 7$ & $7 / 8$ & 341.0 & 41.3 & 6.6 & 6.876 & 48 & & & Floor 1 non b S2R3 N352 E397 \\
\hline $\mathrm{Xa} 8$ & $6 / 6$ & - & - & - & - & - & & rejected & Floor 1 non b S2R1 N349 E397 \\
\hline $\mathrm{Xa9}$ & $6 / 6$ & - & - & - & - & - & & rejected & Wall non b S2R3 N344 E399 \\
\hline Xa10 & $6 / 6$ & - & - & - & - & - & & rejected & Floor 1 non b S9B1 N350 E368 \\
\hline Xa11 & $4 / 4$ & 47 & 39.3 & 20.42 & 3.784 & 14 & & rejected & Floor 2 non b S9B2 N350 E368 \\
\hline $\mathrm{Xa} 12$ & $6 / 6$ & 336.8 & 48.4 & 20.1 & 5.380 & 8 & & rejected & Floor 3 non b S9B3 N350 E363 \\
\hline Xa13 & $4 / 4$ & 350.0 & 66.2 & 28.93 & 3.596 & 7 & & rejected & Floor 4 non b S9B4 N356 E370 \\
\hline Xa14 & $6 / 8$ & 1.8 & 51.1 & 19.42 & 5.611 & 19 & & rejected & $\begin{array}{l}\text { Floor Square. Red building } \\
\text { S9B4 N356 E370 }\end{array}$ \\
\hline Xa15 & $4 / 7$ & 359.3 & 41.4 & 29 & 3.592 & 7 & & rejected & Floor 1 non b S9B5 N346 E359 \\
\hline Stage & $N$ & DEC & INC & $\alpha_{95}$ & $R$ & $K$ & $\begin{array}{l}\text { Probable } \\
\text { dates AD }\end{array}$ & $\begin{array}{c}\text { Archaeomagnetic } \\
\text { dating } \mathrm{AD}\end{array}$ & \\
\hline $\begin{array}{l}\text { Floor } 1 \mathrm{~b} \\
\quad \mathrm{~S} 4\end{array}$ & $4 / 4$ & 352.4 & 40.5 & 9.8 & 3.928 & 45 & $\begin{array}{c}550-575 \\
1155 \\
1375-1454 \\
1460-1494\end{array}$ & $550-575$ & \\
\hline $\begin{array}{c}\text { Floor } 1 \\
\text { non b S4 }\end{array}$ & $2 / 2$ & 345.9 & 39.4 & 32.69 & 1.967 & 31 & & rejected & \\
\hline $\begin{array}{c}\text { Floor } 1 \\
\text { non b S2 }\end{array}$ & $1 / 2$ & 341.0 & 41.3 & 6.6 & 6.876 & 48 & $\begin{array}{c}250-350 \\
575-650 \\
1155-1195\end{array}$ & none & \\
\hline
\end{tabular}

was sampled for archaeomagnetic dating earlier by HuedaTanabe et al. (2004). The new samples collected complement the initial study. Samples consist mainly of burned stuccos dated as $550 \mathrm{AD}$ by radiocarbon dating and additional unburned specimens (containing fine grained scoria) covering the time interval between AD 100 and AD 350. A total of 153 oriented samples were collected for the study (Tables 1, 2 and 3).

Teopancazco is a neighborhood compound at the southeastern sector of the city of Teotihuacan, which is characterized by a series of constructive levels built during the Classic (AD 200-600/650) as well as the Epiclassic, and Aztec 
Table 2. Mean directions by sample and stage of Xalla 2003. $N$ : number of specimens, DEC: declination, INC: inclination, $\alpha_{95}, R, K$ : Fisher statistical parameters, b-burned, non b-non burned location parameters: $\mathrm{S}$-structure, $\mathrm{N}$-north, E—east.

\begin{tabular}{|c|c|c|c|c|c|c|c|c|c|}
\hline Sample & $N$ & DEC & INC & $\alpha_{95}$ & $R$ & $K$ & & & Description \\
\hline $\mathrm{X} 1$ & $4 / 4$ & 355.5 & 38.4 & 3.95 & 3.994 & 541 & & & Floor $1 \mathrm{~b} \mathrm{~S} 1$ \\
\hline $\mathrm{X} 2$ & $4 / 4$ & 354.7 & 36.1 & 4.88 & 3.991 & 355 & & & $\begin{array}{l}\text { Floor } 1 \text { b S1 } \\
\text { N385 E369 }\end{array}$ \\
\hline $\mathrm{X} 3$ & $3 / 3$ & 4.3 & 41.9 & 11.7 & 2.982 & 112 & & & $\begin{array}{l}\text { Floor } 1 \text { b S1 } \\
\text { N380 E370 }\end{array}$ \\
\hline $\mathrm{X} 4$ & $1 / 1$ & 353.5 & 41.2 & - & - & - & & & $\begin{array}{l}\text { Floor } 1 \text { b S1 } \\
\text { N378 E370 }\end{array}$ \\
\hline $\mathrm{X} 5$ & $2 / 2$ & 356.5 & 34.6 & 2.24 & 1.999 & 12373 & & & $\begin{array}{l}\text { Floor } 1 \text { b S1 } \\
\text { N378 E369 }\end{array}$ \\
\hline $\mathrm{X} 7$ & $1 / 1$ & 343.5 & 39.3 & - & - & - & & & $\begin{array}{l}\text { Red wall } \\
\text { N361 E378 }\end{array}$ \\
\hline $\mathrm{X} 8$ & $4 / 4$ & 356.3 & 45.8 & 2.89 & 3.997 & 1006 & & & $\begin{array}{l}\text { Red wall } \\
\text { N380 E361 }\end{array}$ \\
\hline X9 & $8 / 8$ & 355.1 & 42.6 & 2.09 & 7.990 & 700 & & & $\begin{array}{l}\text { Red wall } \\
\text { N380 E361 }\end{array}$ \\
\hline Stage & $N$ & DEC & INC & $\alpha_{95}$ & $R$ & K & $\begin{array}{l}\text { Probable } \\
\text { dates AD }\end{array}$ & $\begin{array}{c}\text { Archaeomagnetic } \\
\text { dating } \mathrm{AD}\end{array}$ & \\
\hline $\begin{array}{c}\text { Floor } 1 \\
\text { b S1 }\end{array}$ & $5 / 5$ & 356.8 & 38.5 & 3.57 & 4.988 & 331 & $\begin{array}{l}350-425 \\
525-550 \\
550-575\end{array}$ & $525-575$ & \\
\hline $\begin{array}{l}\text { Red } \\
\text { Walls }\end{array}$ & $3 / 3$ & 351.4 & 42.7 & 8.11 & 2.988 & 172 & $545-605$ & $545-605$ & \\
\hline
\end{tabular}

Table 3. Mean directions by sample and stage of Teopancazco 2003. $N$ : number of specimens, DEC: declination, INC: inclination, $\alpha_{95}, R, K$ : Fisher statistical parameters. Remagnetization circles: method employed (or used) to estimate mean direction b-burned, non $b-$ non burned location parameters: $\mathrm{R}$-room, $\mathrm{N}$-north, $\mathrm{E}$ - east.

\begin{tabular}{|c|c|c|c|c|c|c|c|c|c|}
\hline Sample & $N$ & $\mathrm{DEC}$ & INC & $\alpha_{95}$ & $R$ & $K$ & & & Description \\
\hline $\mathrm{T} 1$ & $6 / 6$ & 353.9 & 46.3 & 4.23 & 5.9801 & 251 & & & Floor 2 b R154-160 \\
\hline $\mathrm{T} 2$ & $4 / 4$ & 346.2 & 35 & & & & & $\begin{array}{l}\text { Remagnetization } \\
\text { circles }\end{array}$ & $\begin{array}{l}\text { Floor } 2 \text { b R153 N464 } \\
\text { E108 }\end{array}$ \\
\hline $\mathrm{T} 3$ & $2 / 2$ & 346.9 & 31.5 & & & & & $\begin{array}{l}\text { Remagnetization } \\
\text { circles }\end{array}$ & $\begin{array}{l}\text { Floor } 2 \text { b R } 153 \text { N464 } \\
\text { E108 }\end{array}$ \\
\hline $\mathrm{T} 4$ & $5 / 5$ & 354.2 & 35.2 & 2.07 & 4.9971 & 1360 & & & $\begin{array}{l}\text { Floor } 1 \text { non } b \\
\text { Temple floor }\end{array}$ \\
\hline Stage & $N$ & DEC & INC & $\alpha_{95}$ & $R$ & $K$ & $\begin{array}{l}\text { Probable } \\
\text { dates } \mathrm{AD}\end{array}$ & $\begin{array}{c}\text { Archaeomagnetic } \\
\text { dating } \mathrm{AD}\end{array}$ & \\
\hline $\begin{array}{c}\text { Floor } 2 \\
\text { b }\end{array}$ & $3 / 3$ & 348.7 & 37.4 & 10.32 & 2.978 & 92 & $\begin{array}{l}100-250 \\
250-350\end{array}$ & $250-350$ & \\
\hline $\begin{array}{l}\text { Floor } 1 \\
\text { non b }\end{array}$ & $1 / 1$ & 354.2 & 35.2 & 2.07 & 4.9971 & 1360 & $\begin{array}{l}350-425 \\
525-550\end{array}$ & $350-425$ & \\
\hline
\end{tabular}

times. The site has been excavated and studied extensively and interdisciplinary, including chemical, palaeobotanical, archaeozoological, osteological, genetical, isotopic and archaeological analyses (Manzanilla, 2000, 2003). Xalla is a palatial compound to the north of the Pyramid of the Sun. It seems to be the rulers' palace because of its dimensions, type of constructions and it was walled. Five constructive stages are recognized at Xalla. Radiocarbon dates of AD 200-250 (Rattray, 1991) and AD 350-550 (Manzanilla and López Luján, 2001) have been reported.

Samples were recovered using non-magnetic chisels, spatulas, and hammers. Each sample was oriented with a magnetic compass and marked with a waterproof pen. In the laboratory, specimens were obtained from each sample.
They were cut with a blade and were "encapsulated" within two wooden discs of $2.5 \mathrm{~cm}$ diameter and about $1.25 \mathrm{~cm}$ thick, using a non-magnetic epoxic resin, in order to obtain cylindrical samples that fit in a spinner magnetometer.

\section{Magnetic Measurements \\ 3.1 Hysteresis experiments}

All samples were subjected to magnetic hysteresis experiments using an AGFM "Micromag" apparatus in fields up to 1.2 Tesla. The hysteresis parameters (saturation remanent magnetization $J_{r s}$, saturation magnetization $J_{s}$, and coercive force $H_{c}$ ) were calculated after correction for paramagnetic contribution. Coercivity of remanence $\left(H_{c r}\right)$ was determined by applying a progressively increasing back-field 

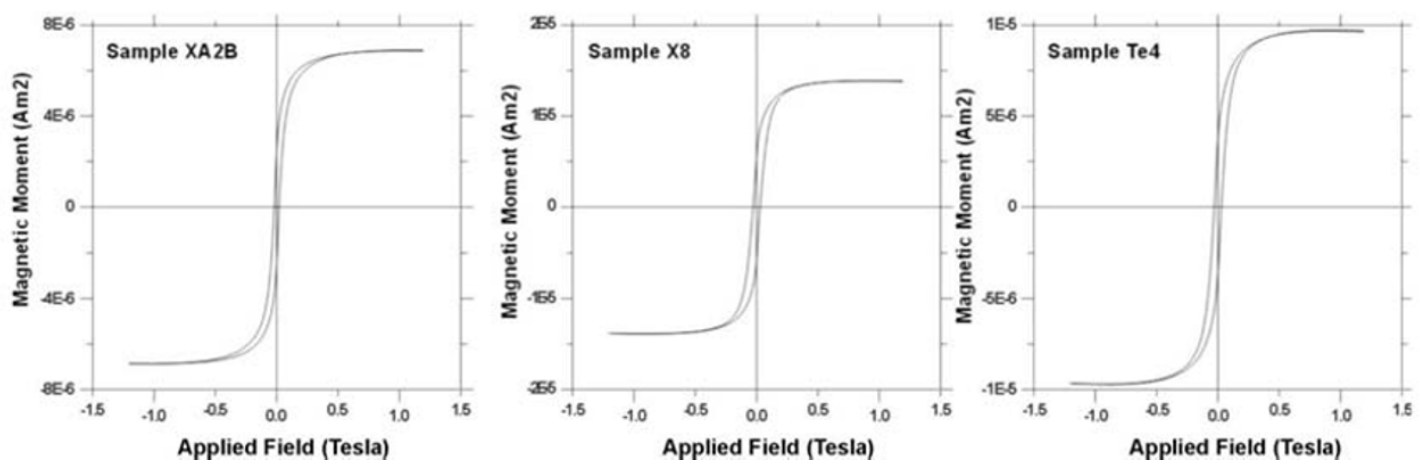

Fig. 2. Hysteresis plots for Xalla samples $2 \mathrm{~B}$ and 8 and Teopancazco 4.
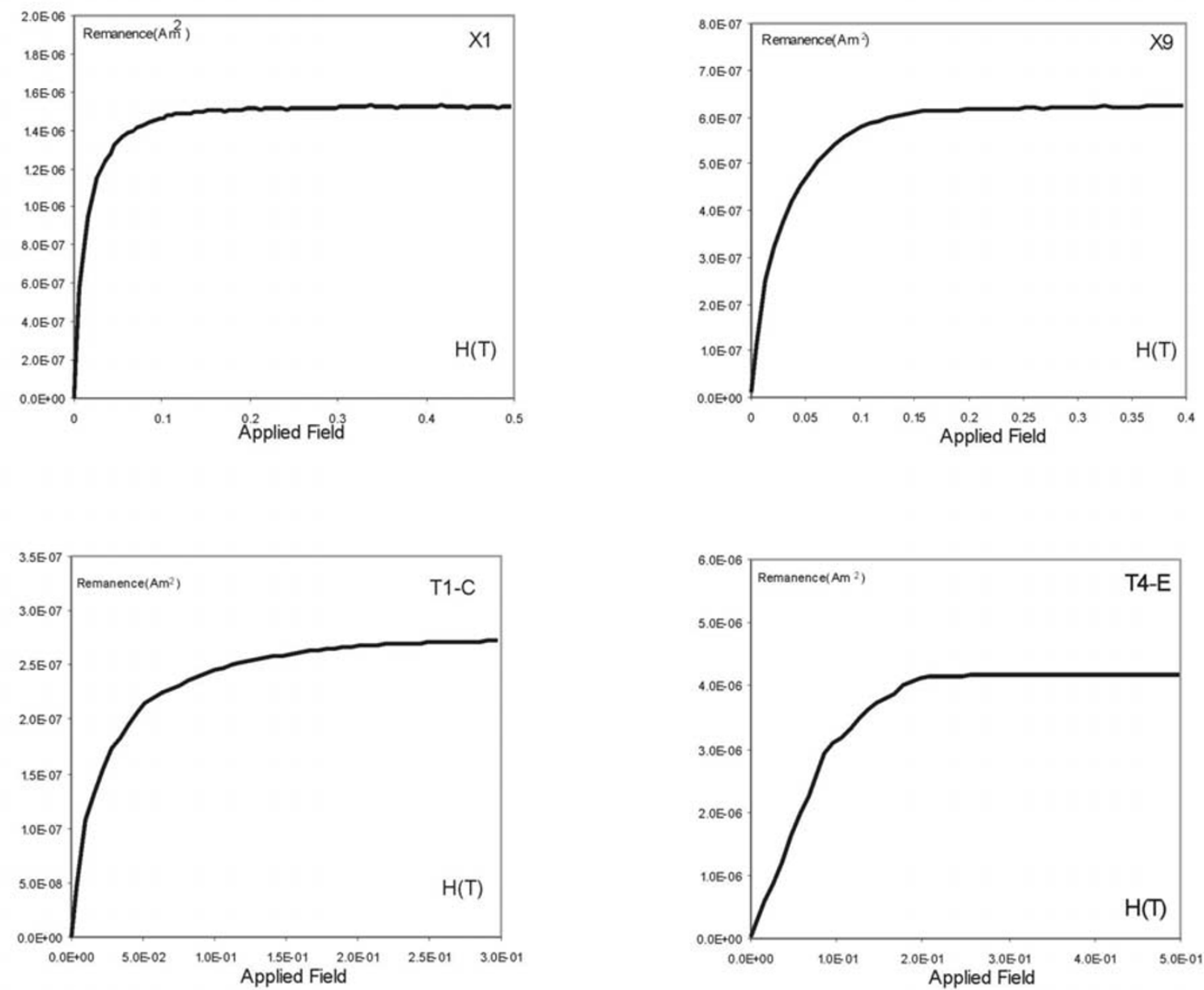

Fig. 3. Isothermal remanent magnetization curves of samples of Xalla 2003 (X1-A and X9-A) and Teopancazco (T1-C y T4-E).

after saturation. Typical hysteresis plots are shown in Fig. 2; the curves are quite symmetrical in all cases. Near the origin no potbellied and wasp-waisted behaviors were detected (Tauxe et al., 1996), which probably reflect very restricted ranges of the magnetic mineral coercivities. In the ratio plot of hysteresis parameters (Fig. 4), samples fall in the pseudo-single-domain (PSD) grain size region (Day et al., 1977; Dunlop, 2002). Isothermal remanent magnetization (IRM) acquisition curves (Fig. 3) indicate that saturation is reached in moderate fields of 100-200 mT, which points to some spinels as remanence carriers (most probably titano- magnetites).

\subsection{Remanence properties}

Natural remanent magnetism (NRM) intensity and direction of each specimen were measured with a AGICO LtD spinner magnetometer JR6 (nominal sensitivity $\sim 10^{-9}$ $\mathrm{Am}^{2}$ ) in the Paleomagnetic Laboratory of the National University of Mexico (UNAM). The coercivity, stability and vectorial composition of NRM were investigated by detailed stepwise alternating field (AF) demagnetization. AF demagnetization was carried out in 8-12 steps up to maximum fields of $100 \mathrm{mT}$ using a Molspin AF demagnetizer. 


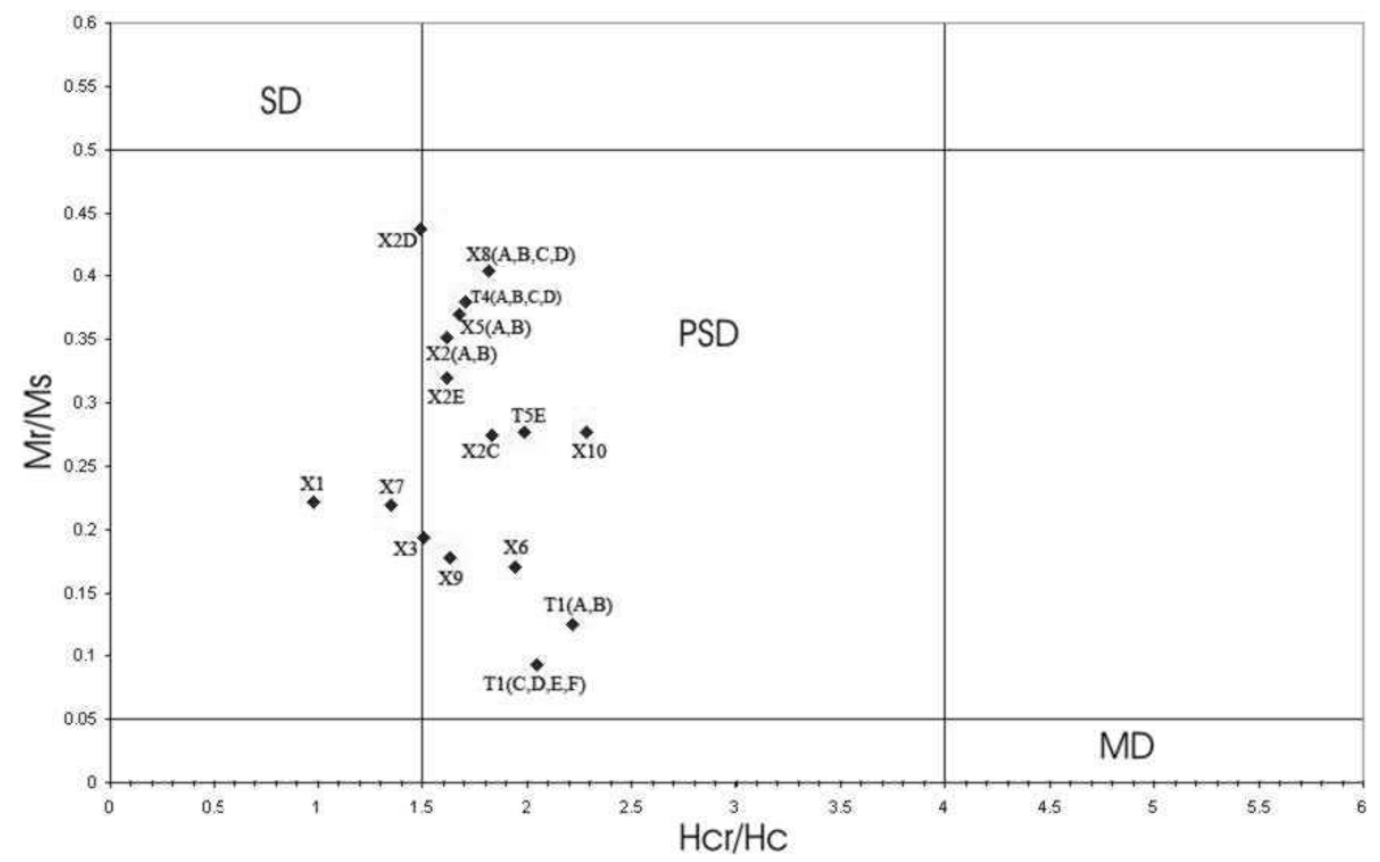

Fig. 4. Plot of Hysteresis parameter ratios and domain state fields (Day et al., 1977; Dunlop, 2002). Xalla (X) and Teopancazco (T) samples 2003.
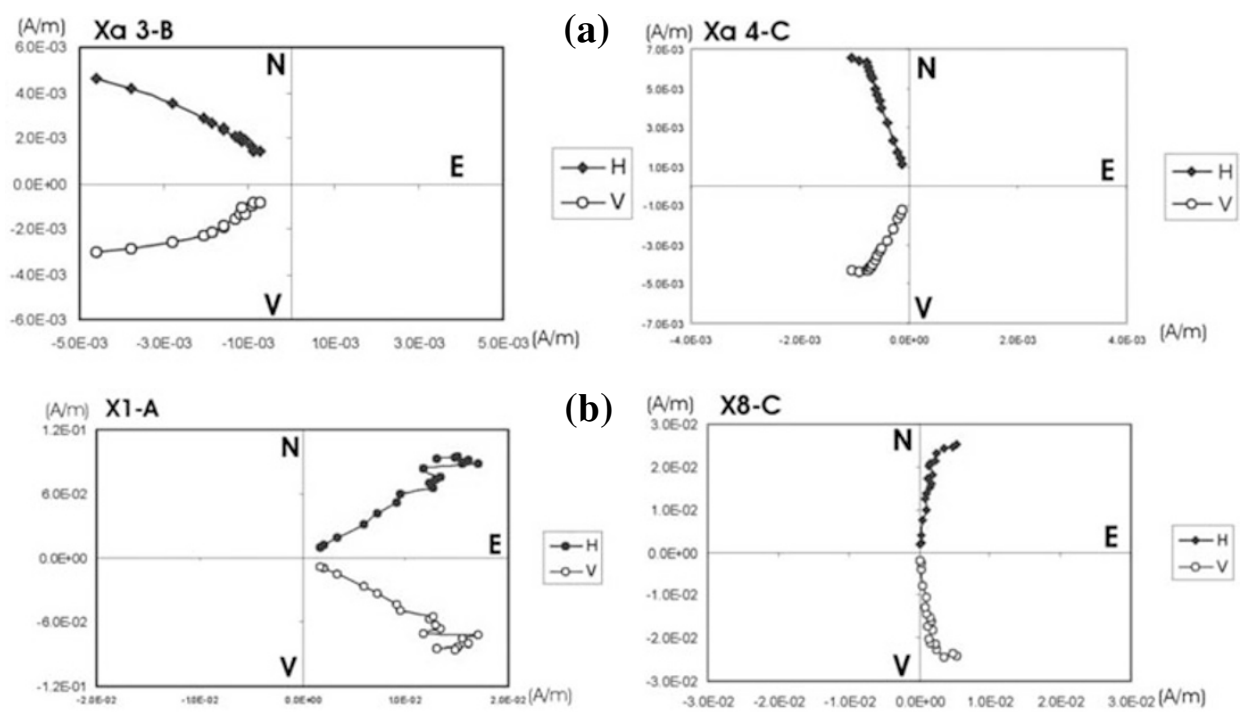

(b)
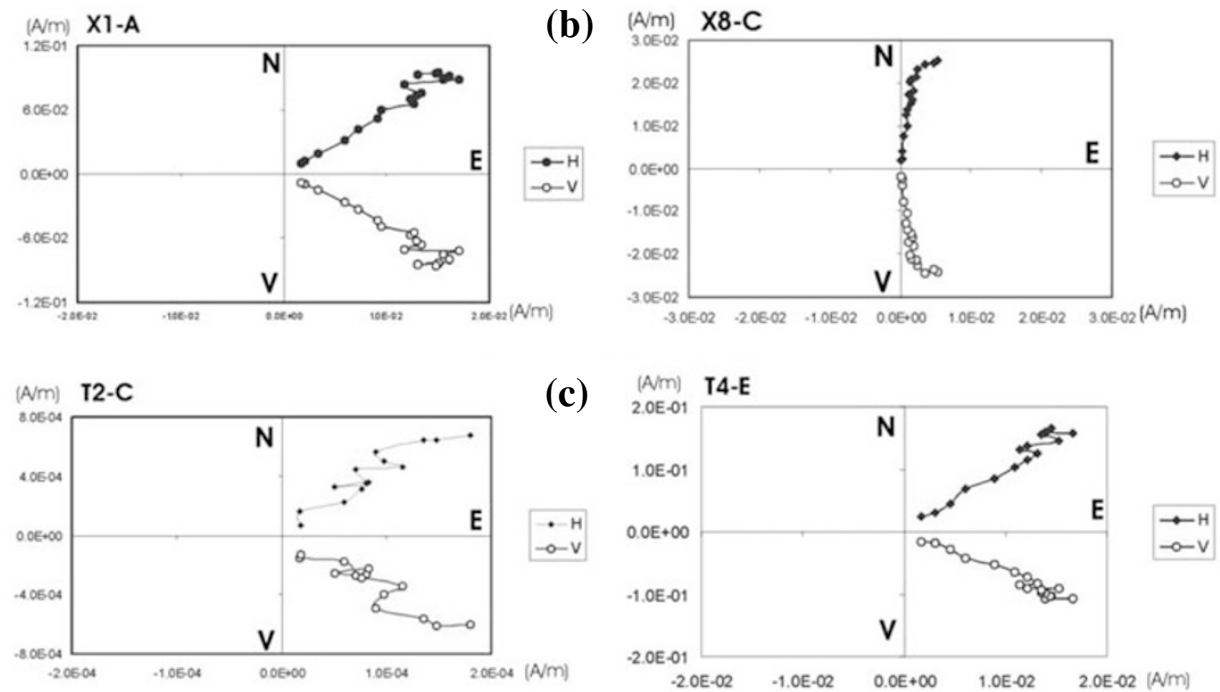

(c)

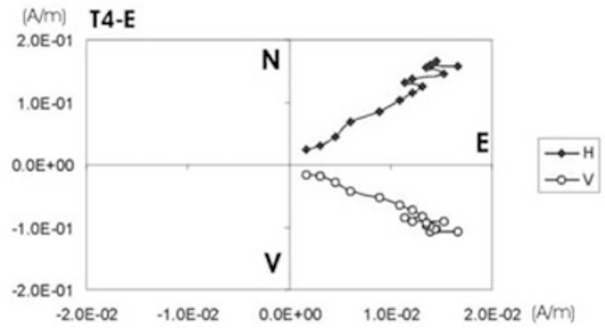

Fig. 5. (a) Demagnetization vector diagrams for samples from Xalla 2001, samples Xa3B and Xa4C. (b) Demagnetization vector diagrams for samples from Xalla 2003, samples X1- A and X8-C. (c) Demagnetization vector diagrams for samples from Teopancazco 2003, samples T2-C and T4-E, full circles-Horizontal component, empty circles-Vertical component.

In most cases stable univectorial components were isolated (Figs. 5(a), (b) and (c)). A small component, probably of viscous origin, is easily removed at first steps of demagnetization. Results are summarized in Tables 1 and 2 for Xalla and in Table 3 for Teopancazco. The characteristic re- manent magnetization (ChRM) direction was calculated by principal component analysis (Kirschvink, 1980) or from vector substraction on the linear vector trajectories going through the origin in the orthogonal diagrams. The remanence directions are listed in Tables 1,2 and 3. The mean 


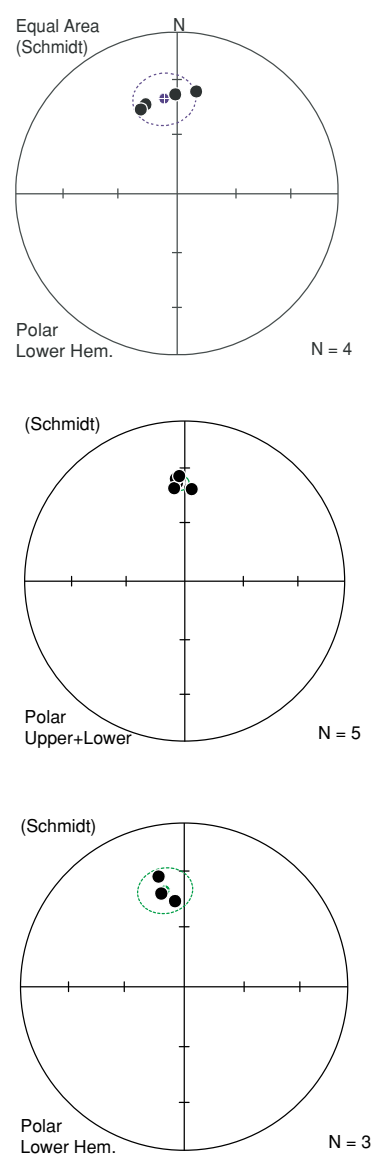

(a)

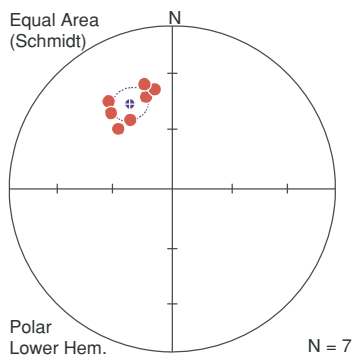

(b)

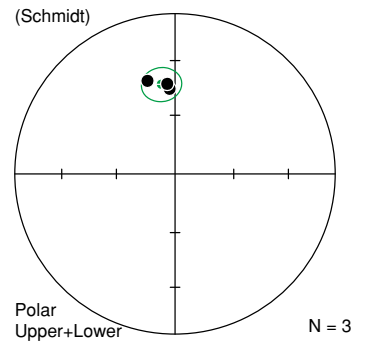

(c)

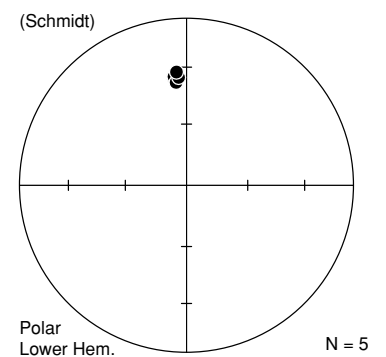

Fig. 6. (a) Average directions for Floor 1 Structure 4 burned and Floor 1 Structure 2 non burned of Xalla 2001. (b) Average directions for Floor 1 burned and the Red Walls of Xalla 2003. (c) Average directions for Floor 2 and Floor 1 unburned of Teopancazco 2003.

directions and angular dispersion parameters for each stage were determined by vector sum giving unit weight to individual specimen directions and assuming a Fisherian statistical distribution of vectors (Tarling, 1983). Mean directions are plotted in equal-area projections (Figs. 6(a), (b) and (c)).

\section{Discussion and Main Results}

Characteristic magnetization directions are successfully isolated for all samples. The $\alpha_{95}$ for unburned materials (it can not be ascertained that the remanence is a detrital remanent magnetization) is higher than burned lime-plasters (probably thermoremanent magnetization). This is clearly shown in Table 1 yielding $\alpha_{95}$ as high as $29^{\circ}$ (single case, sample Xa13). In any case, all samples yielding $\alpha_{95}$ higher than $13^{\circ}$ were discarded from further analysis.

From the statistical analyses we estimated the magnetic declination and inclination of the ChRM of each sample and mean site directions. We calculated the virtual geomagnetic pole (VGP) for sites from each constructive stage. The sitemean directions and VGPs were then compared to the available PSV reference curve for Mesoamerica. An improved PSV curve of Central Mexico has been used (Hueda-Tanabe et al., 2004), with incorporation of data reported in UrrutiaFucugauchi (1975, 1996), Wolfman (1973, 1990), OrtegaGuerrero and Urrutia-Fucugauchi (1997) (lake sediments)

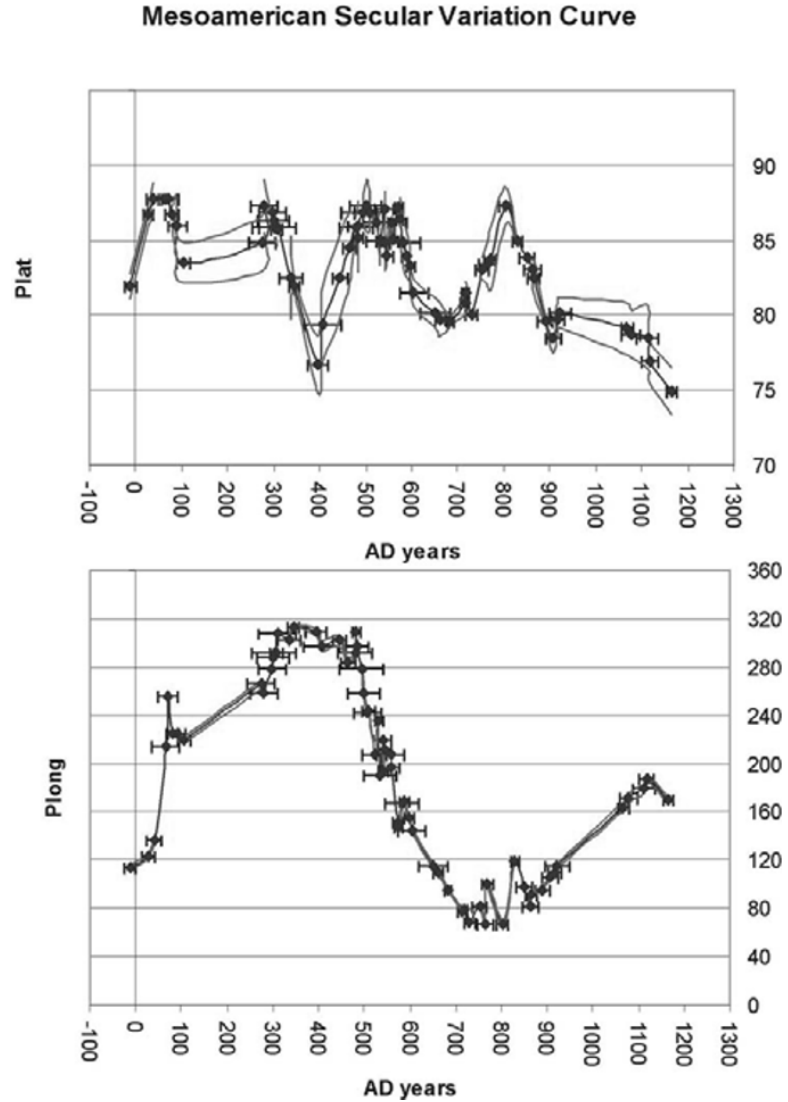

Fig. 7. Geomagnetic secular variation curve of Mesoamerica (Hueda-Tanabe et al., 2004).

and Latham et al. (1986) (stalagmites). Some additional results from volcanic rocks, historical and observatory data are also considered (Fig. 7). For the dating purposes, we employed a basic principle of archaeomagnetic dating (Le Goff et al., 2002; Noel and Batt, 1990) that consists in finding the "crossing-point" with the palaeosecular curve of the region. In addition, some stratigraphic restrictions are considered to better constrain the dates.

Xalla 2001 mean site directions of floor 1 burned S4 and -non burned S2 show well clustering with $\alpha_{95}$ less than $10^{\circ}$. The floors 2, 3, 4 and 5 however are poorly defined and yield relatively high dispersion, which impedes any possibility of age estimation. Generally speaking the results of Xalla 2003 for floor 1 burned showed better clustering $\left(\right.$ Dec $=356.8$, Inc $\left.=38.5, \alpha_{95}=3.6\right)$ than Xalla 2001 $\left(\right.$ Dec $=0.4$, Inc $\left.=39.9, \alpha_{95}=9.8\right)$. Both directions however are undistinguishable at $95 \%$ level. These results point to dates of AD 550-575 and AD 525-575 respectively yielding an average of AD $550 \pm 25$. This matches with the date of AD 555 for the Big Fire of Teotihuacan (Beta 115496; Manzanilla, 2003).

Estimated archaeomagnetic dates for the Xalla site (Floor 1-S4 and S2 burned, corresponding to 2001 and 2003 collections) agree well within error to previous dates reported in preliminary work of Hueda-Tanabe et al. (2004). Unfortunately, the present study does not allow to estimate the age of the consecutive construction stages (Floor $1 \mathrm{~S} 4$ non burned, Floor 2, 3 and 4 from Structure 9 and Floor 1 non 
burned from Structure 4) due to the high directional dispersion. On other hand, our estimated dates for the red walls (AD 545-605), seems to indicate that they have been affected by documented Big Fire matches well with the archaeological dates (AD 575, Beta 115496; Manzanilla, 2003) or a reparation of the wall.

The Teopancazco mean directions for $2003 \mathrm{~T} 1$ and T4 showed good clustering. All $\alpha_{95}$ are less than $5^{\circ}$. It should be noted that mean directions for samples T2 and T3 has been calculated by remagnetization circles. Again, basically similar directions are obtained from burned and unburned lime-plasters (Table 3). The new archaeomagnetic dates obtained here for the Teopancazco site (floor 1 unburned from Temple Floor) coincide quite well with those reported by Hueda-Tanabe et al. (2004) for the sample TP6. Additionally dates obtained for floor 1 (non burned, Temple Floor) agree with age estimation for sample TP2 of HuedaTanabe et al. (2004) and with the radiocarbon date of AD $350 \pm 40$ (Beta 132605, Manzanilla, 2000).

Acknowledgments. This study forms part of the UNAM collaboration program between the Institute of Geophysics and Institute of Anthropological Research. Constructive comments by two journal reviewers are highly appreciated. AG is grateful to the financial support of UNAM-PAPIIT project IN100403.

\section{References}

Aitken, M. J., Science-based Dating in Archaeology, Longman Archaeology Series, Longman, pp. 225-259, 1990.

Day, R., M. Fuller, and V. A. Schmidt, Hysteresis properties of titanomagnetites: grain size and compositional dependence, Phys. Earth Planet. Inter., 13, 260-267, 1977.

Dunlop, D. J., Theory and application of the Day plot $\left(M_{r s} / M_{s}\right.$ versus $\left.H_{c r} / H_{c}\right)$ 1. Theoretical curves and tests using titanomagnetite data, $J$. Geophys. Res. B: Solid Earth, 107(3), 5-1-5-15, 2002.

Genevey, A. and Y. Gallet, Intensity of the geomagnetic field in western Europe over the past 2000 years: New data from ancient French pottery, J. Geophys. Res., 107(B11), 2285, doi:10.1029/2001JB000701, 2002.

Hueda-Tanabe, Y., A. M. Soler-Arechalde, J. Urrutia-Fucugauchi, L. Barba, L. Manzanilla, M. Rebolledo, and. A. Goguitchaishvili, Archaeomagnetic studies in central México-dating of Mesoamerican lime-plasters, Phys. Earth Planet. Int., 147, 269-283, 2004.

Kirschvink, J. L., The least-square line and plane and the analysis of palaeomagnetic data, Geophysical Journal of the Astronomical Society, 62, 699-718, 1980.
Lanos, P., M. Kovacheva, and A. Chauvin, Archaeomagnetism, methodology and applications: implementation and practice of the archeaomagnetic method in France and Bulgaria, European J. Archaeology, 2(3), 365-392, 1999.

Latham, A. G., H. P. Schawrz, and D. C. Ford, The paleomagnetism and UTh dating of Mexican stalagmite. Earth Planet. Sci. Lett., 79, 195-207, 1986.

Le Goff, M., Gallet, Y., Genevey, and A. Warmé, N. On archeomagnetic secular variation curves and archeomagnetic dating, Phys. Earth Planet. Inter., 4160, 1-9, 2002.

Manzanilla, L., 1998-2000 Informes técnicos entregados al Consejo de Arqueología del INAH, Unpublished Internal Report, 2000.

Manzanilla, L. R., Teopancazco: un conjunto residencial teotihuacano, Arqueología Mexicana, XI(64), 50-53, 2003.

Manzanilla, L. and L. López Luján, Exploraciones en un posible palacio de Teotihuacan: El Proyecto Xalla (2000-2001), Mexicon, XXIII(3), 58-61, 2001.

Manzanilla, L., Metrópolis prehispánicas e impacto ambiental: el caso de Teotihuacan a través del tiempo, Volumen especial de la UMEC, (Margarita Caballero, ed.), Fondo de Cultura Económica (in press).

Noel, M. and C. Batt, A method for correcting geographically separated remanence directions for the purpose of archaeomagnetic dating, Geophys. J. Int., 102, 753-756, 1990.

Ortega-Guerrero, B. and J. Urrutia Fucugauchi, A paleomagnetic secular variation record from Late Pleistocene-Holocene lacustrine sediments from Chalco lake, basin of Mexico, Quaternary International, 43/44, 87-96, 1997.

Rattray, E. Ch., Fechamientos por radiocarbono en Teotihuacan, in Arqueología, 6, segunda época, 3-18, 1991.

Tarling, D. H., Palaeomagnetism. Principles and Applications in Geology, Geophysics and Archaeology, 379 pp., Chapman and Hall, London, 1983.

Tauxe, L., T. A. T. Mullender, and T. Pick, Potbellies, wasp-waists, and superparamagnetism in magnetic hysteresis, J. Geophys. Res., 101(B1), 571-583, 1996.

Urrutia-Fucugauchi, J., Investigaciones paleomagnéticas y arqueomagnéticas en México, Anales Instituto de Geofsica, 21, 27-34, 1975.

Urrutia-Fucugauchi, J., Paleomagnetic study of the Xitle-Pedregal de San Angel lava flow, southern basin of Mexico, Phys. Earth Planet. Inter., 97, 177-196, 1996.

Wolfman, D., A re-evaluation of Mesoamerican chronology: AD 1-1200, Ph.D. Thesis University of Colorado, 1973.

Wolfman, D., Mesoamerican chronology and archaeomagnetic dating, AD 1-1200, in Archaeomagnetic Dating, edited by J. L. Eghmy and R. S. Sternbeg, 446 pp., Univ. Arizona Press, Tucson, Arizona, 1990.

A. M. Soler-Arechalde (e-mail: anesoler@geofisica.unam.mx), F. Sánchez, M. Rodriguez, C. Caballero-Miranda, A. Goguitchaishvili, J. Urrutia-Fucugauchi, L. Manzanilla, and D. H. Tarling 